\title{
Preface: The Past, Present, and Future of the Restatement of Copyright
}

\author{
Shyamkrishna Balganesh ${ }^{*} \&$ Jane C. Ginsburg*
}

It is now six years since the American Law Institute (ALI) began work on its first ever Restatement of an area dominated by a federal statute: copyright law. To say that the Restatement of the Law, Copyright (hereinafter "Restatement") has been controversial would be a gross understatement. Even in its inception, the ALI identified the project as an outlier, noting that it was likely to be seen as an "odd project" since copyright "is governed by a detailed federal statute." Neither the oddity nor the novelty of the project, however, caused the ALI to slow its efforts to push the project forward, and despite the persistence of serious objections from within the membership of the project (including many of the project's Advisers), the first draft of the Restatement is scheduled to go to a vote seeking adoption by the organization's full membership in the middle of 2021.

While the project is itself many years - if not a full decade - away from being anywhere near completion, its controversial origins as well as the debates and disagreements surrounding its format and substantive content have for the most part taken place behind closed doors, in meetings of the Project Advisers and the Members Consultative Group (MCG). News outlets and blogs have periodically carried accounts of some of these disagreements, but they have for the most part refrained from any serious engagement with the specifics of the Restatement itself, or of the process of its drafting. ${ }^{2}$ This is hardly for lack of interest in the copyright world. Instead, it is a direct consequence of the reality that much of the ALI's deliberations occur out of the public eye, and under conditions of confidentiality. Despite having been in existence for nearly a century and committed to the ideal of law reform, the ALI is hardly the bastion of transparency. Members of the bar, bench and legal academy who have no direct affiliation with the ALI remain largely in the dark about a project until it is adopted and thereafter published. Even when that

\footnotetext{
* Sol Goldman Professor of Law, Columbia Law School.

** Morton L. Janklow Professor of Literary \& Artistic Property Law, Columbia Law School.

1. Richard L. Revesz, Our New Projects, 37 A.L.I. ReP. 3, 3 (Spring 2015).

2. See, e.g., Michelle Lewis, The Sneaky Long Game of ALI's Restatement of Copyright, VARIETY (Dec. 13, 2019), https://perma.cc/GU3H-P7E9; Stuart Dredge, Row over ALI 'Restatement of Copyright' Rumbles on in the US, MUSICALLY (Dec. 5, 2019), https://perma.cc/HRL2-XRYX.

(C) 2021 Balganesh \& Ginsburg. This is an open access article distributed under the terms of the Creative Commons Attribution-NonCommercial-NoDerivatives License, which permits noncommercial use, distribution, and reproduction, provided the original authors and source are credited, and the article is not changed.
} 
finally occurs, the extensive history behind the project—its "legislative history" or "file-wrapper history," to use terms from other contexts-is not made public. ${ }^{3}$ The text of a Restatement is meant to speak for itself, masking the complexities and nuances of the restating process. This opacity is less problematic when the judges, academics, and practitioners who make up the ALI agree on the need for the project and the methods of its undertaking. On the other hand, where those fundamental questions about the project have riven participants from the very outset, and the ALI has rejected calls for more careful consideration of the project's premises and methodology, the lack of transparency compounds concerns about the project's legitimacy.

It is with the goal of bringing some degree of transparency and public scrutiny to the project that we, as Advisers to the Restatement, decided to bring together for this Special Issue of the Columbia Journal of Law \& the Arts a group of scholars, lawyers, and judges to discuss and comment on the project. We highlight divergent viewpoints on the project: some supportive, some critical, and some equivocal. We invited a mix of project insiders, who would bring to the conversation their experience during the actual deliberations, as well as outsiders, including practitioners and judges, for their assessment of the project's utility to bench and bar. We had also sought the participation of the project's leadership - its Reporter and Associate Reporters. Unfortunately, they declined our repeated invitations.

The Special Issue that follows features three long Articles and three short Responses to them. ${ }^{4}$ Together, they address a variety of different issues surrounding the Restatement, and from different perspectives. In their contribution, Professors Shyam Balganesh and Peter Menell directly confront the "odd" nature of the project, and its effort to restate an area of law that is the subject of a detailed federal statute. ${ }^{5}$ Their Article examines the reasons for the ALI's historic reluctance to restate areas of federal statutory law, a reluctance that manifested itself rather vividly in the years immediately after the organization's founding. They then show how that reluctance has produced a mismatch between the structure and working of Restatements synthesizing common law and domains of statutory law, which the ALI completely

3. Upon approval and adoption of a project, the ALI makes prior drafts of a Restatement (Tentative Drafts and Council Drafts) available in its archives, much of which is now digitized and available on HeinOnline. Missing from the archives are the (1) comments—written and oral—submitted by project members during the drafting of the Restatement, (2) records of the Advisers and Members Consultative Group meetings, and (3) records of the Council Meetings where the project was considered and discussed. As a private organization, the ALI is obviously not subject to the provisions of the Freedom of Information Act (FOIA).

4. Shyamkrishna Balganesh \& Peter S. Menell, Restatements of Statutory Law: The Curious Case of the Restatement of Copyright, 44 COLUM. J.L. \& ARTS 285 (2021); Jeanne C. Fromer \& Jessica Silbey, Retelling Copyright: The Contributions of the Restatement of Copyright Law, 44 COLUM. J.L. \& ARTS 341 (2021); Justin Hughes, Restating Copyright Law's Originality Requirement, 44 COLUM. J.L. \& ARTS 383 (2021); Jon O. Newman, The Myths of Textualism and Their Relevance To the ALI's Restatement of the Law, Copyright, 44 COLuM. J.L. \& ARTS 411 (2021); Eric J. Schwartz, Restatement of the Law, Copyright: A Useful Resource for Practitioners and the Courts or a Rashomon Exercise?, 44 Colum. J.L. \& ARTS 425 (2021); Joseph P. Liu, Between Code and Treatise: The Hard Challenge of the Restatement of Copyright, 44 COLUM. J.L. \& ARTS 441 (2021).

5. See Balganesh \& Menell, supra note 4. 
ignored in embarking on the Restatement, despite Advisers' multiple constructive efforts to persuade the ALI to think through an appropriate methodology for restating a federal statutory regime. Their Article uses an example from the project to illustrate the mismatch between ALI black letter and statutory text. It ends with a blueprint for the Restatement to adopt in order to overcome the mismatch and its consequences. $^{6}$

Professors Jeanne Fromer and Jessica Silbey praise the Restatement initiative in their Article. ${ }^{7}$ In their view, the Restatement is a worthwhile retelling of copyright law, notwithstanding the statutory origins of the subject. A statute, much like any other text, requires being read and retold in a particular way by the relevant interpretive community, constrained by relevant professional standards and norms. In their view, the Restatement very ably achieves this result. Much of the criticism levelled against the project is, in this account, either misconceived or directed against all of the ALI's Restatements rather than this specific project. Their Article then examines the nuances underlying the Restatement's engagements with various complex doctrinal issues in copyright law to show how it attempts to synthesize the judge-made law in the domain with the wording of the statute, building Congress's vision of having its directives extended and applied to new technological contexts. They thus see in the specifics of the Restatement a subtlety, care, and candor that make it worthwhile for judges and lawyers to embrace. ${ }^{8}$

In his contribution to the issue, Professor Justin Hughes focuses on the Restatement's treatment of copyright's principal threshold requirement for protection: originality. ${ }^{9}$ In a detailed and careful examination of the Restatement's provisions on the topic and its evolution, he shows how the project's approach is modeled on the Supreme Court's principal examination of originality, in Feist v. Rural Telephone. ${ }^{10}$ The Article highlights various concerns with the way in which the Restatement seeks to give effect to the "creativity" requirement developed by the Court in Feist, including the Restatement's failure to fully address the principle of aesthetic neutrality, and its attempt to limit "selection, coordination and arrangement" exclusively to compilations. ${ }^{11}$

Hughes goes on to highlight how the Restatement - in both the black letter and the comments - embellishes standards that originate in the case-law by introducing additional components which have the effect of altogether altering the standard. One such example is the Restatement's assertion that independent creation-as a component of originality-requires that "it must come from the mind of the author." 12 As Hughes points out, under current law a work of authorship need not originate from a conscious application of the creator's mind; the author may adopt

6. Id at 337-40.

7. See Fromer \& Silbey, supra note 4.

8. Id. at 344 .

9. See Hughes, supra note 4.

10. 499 U.S. 340 (1991)

11. Hughes, supra note 4, at 390-96.

12. ReStATEMENT OF THE LAW, COPYRIGHT $\S 6 \mathrm{cmt}$. a, at 58 (AM. L. INST., Tentative Draft No. 1, Apr. 8, 2020). 
the results of an inadvertently creative act. The Article concludes that the Restatement does a fair job at sticking to a "centrist, sometimes minimalist" narrative of the doctrine but nevertheless contains errors and modifications-some of which may have been intentional - that deserve correction so as to avoid inaccuracy. ${ }^{13}$

The three shorter Responses echo many of the themes addressed by the principal papers. In his contribution, Judge Jon Newman addresses the connection between textualism and the Restatement project by noting how the textualist reluctance to engage the legislative history of a statute is deeply problematic. Echoing the suggestion made by Balganesh and Menell, he argues that the legislative history of the copyright statute remains a particularly helpful interpretive source for federal judges deciding copyright cases. ${ }^{14}$ He also concludes that in an area covered by a detailed statute like copyright, the Restatement should include the entire text of the relevant statutory provision and the Reporters' formulation of their black letter, since to do just the latter without the former-as the project currently does-would add more confusion to the area. ${ }^{15}$

In his Response, Eric Schwartz examines the utility of a Restatement initiative in a domain covered by a detailed statute. Noting that different parts of the copyright statute entail different levels of judicial exposition, Schwartz expresses deep skepticism about the Restatement's treatment of statutory text, but identifies areas of judge-made copyright law where the Restatement could be most helpful. He concludes by arguing that the project would be most credible and useful to judges and practitioners, if it trimmed out most of its statutory "re-workings" and instead focused exclusively on the judge-made components of copyright. ${ }^{16}$

Last, but by no means least, Professor Joseph Liu surveys the principal Articles in the issue and uses his Response to offer his views of the Restatement and its role within the copyright skein. Observing that the Reporters of the project took on the task of dealing with a complex regime whose norms derive from different institutions, legislative, judicial, and administrative, he sees Balganesh and Menell and Fromer and Silbey as offering two competing attitudes to the Restatement. An unappreciated feature of the project that Liu identifies is the mismatch between what the project $i s$ and what it attempts to be, which in his view has contributed to questions about the legitimacy of the project. ${ }^{17}$ While it purports to be modeled on traditional common law restatements, he notes that it sits somewhere between a good treatise and a sophisticated annotated code, raising questions about its very utility. Given the novelty and complexity of the endeavor, Liu concludes that this perception gap is unlikely to go away and that the Restatement will always be seen as being in competition with the statute. ${ }^{18}$

Together, these six contributions offer a wide-ranging, balanced account of the Restatement, highlighting its many strengths and weaknesses and suggesting

13. Hughes, supra note 4, at 409.

14. Newman, supra note 4, at 419-20.

15. Id. at 423 .

16. Schwartz, supra note 4 , at 439 .

17. Liu, supra note 4 , at $453-54$.

18. Id. at $454-55$. 
modifications in both form and substance to improve the project. They offer different perspectives from within the copyright system-of academics, a judge, and a copyright practitioner; and they focus on different aspects of the project. As the project heads into its first full-membership vote, our hope is that ALI members - not otherwise acquainted with copyright law or the Restatement-will find these contributions beneficial and will pay close attention to the many concerns and suggestions for improvement and remediation that the contributions call for. 